\title{
Efficacy of Monosodium Glutamate as a Flavour Potentiator in Salt Reduction: A Review
}

\author{
Prabhavathi S.N and Jamuna Prakash* \\ Department of Food Science and Nutrition, Manasagangothri, University of Mysore, Mysore-06, India.
}

* Corresponding Author: Jamuna Prakash, Department of Food Science and Nutrition, Manasagangothri, University of Mysore, Mysore. India. E-mail: jampr55@hotmail.com

Received date: August 03, 2019; Accepted date: August 14, 2019; Published date: August 20,2019

Citation: Prabhavathi S.N and Jamuna Prakash, Department of Food Science and Nutrition, Manasagangothri, University of Mysore, Mysore, India. J Nutrition and Food Processing, 2(1): Doi: 10.31579/2637-8914/008.

Copyright:@ 2019 Jamuna Prakash. This is an open-access article distributed under the terms of The Creative Commons Attribution License, Which permits unrestricted use, distribution, and reproduction in any medium, provided the original author and source are credited.

\begin{abstract}
Sodium is an essential micro nutrient and an indispensable ingredient in most of the savoury foods. The salty taste is mainly contributed by sodium chloride through a proto-typical stimulus. The current sodium intake has been estimated to be exceeding normal recommendation at an alarming rate. This has given rise to health concerns since excessive sodium intake is associated with rise in blood pressure and eventually to cardiovascular diseases. The habitual salt intake among Asian population is around 10-12g/day against the WHO recommendation of 5-6g/day. Today food processing industries are facing challenges pertaining to sodium reduction, since it reduces the overall acceptability. In any food sodium can be reduced through a gradual lowering of salt level, however, this would require several months since it also decreases the overall palatability of foods. Another strategy that can be adopted to overcome this problem is to employ salt substitutes like monosodium glutamate (MSG). MSG has $30 \%$ less sodium in comparison to table salt and can help maintain palatability of foods. There are many studies supporting this observation. Our studies on the acceptability profile of salt reduced MSG incorporated fried preparations showed that approximately $25 \%$ of salt could be reduced in products without any significant effect on flavor profile. The results indicated that spice added product could be consumed with lower sodium levels and MSG had synergistic effect with spices. In salt reduced tomato soups, the control product with low salt was given lower scores as against MSG incorporated samples. It was also observed that increasing levels of MSG resulted in higher acceptance of products. Hence, it can be said that using MSG as a substitute would be a better option for maintaining adequate palatability in savoury foods with reduced sodium content.
\end{abstract}

Key words: flavour enhancer; sodium reduction; salt substitutes; glutamates; sensory profile; palatability

\section{Introduction}

Sodium chloride is considered as an indispensable ingredient in most of the processed savoury products. The salty taste contributed by sodium chloride is a prototypical stimulus [1]. Sodium is known to improve various sensory properties of food; mainly by increasing saltiness and sweetness, decreasing bitterness and also bringing about other congruent flavor effects [2]. The overall liking and acceptance of salty foods and their governing factors are not well understood. Certain environmental factors like, level of sodium in diet and sodium content in habitual diet are proposed to have a significant role $[3,4]$. Sodium is an essential element needed for maintaining normal physiological functions. The estimated current sodium intake of populations across the world seems to be exceeding the normal recommendation [5] and is not showing any decline. This has raised concerns regarding the safety of consumers since high sodium intake is strongly associated with an increase in blood pressure. Apart from this, it is also known to have other negative health effects such as gastric cancer and decreased bone mineral density [6].

It has been reported that a modest $15 \%$ reduction in sodium intake can prevent cardiovascular disease related deaths all over the world over in 10 years [7]. Despite its negative health consequences, humans are still continuing to consume sodium in the form of salt in amounts well above the recommended levels in most of the developed countries. Hence, this should become the prime priority for public health and well being. Due to this, a wide variety of strategies to reduce sodium in different food matrices have been tried. However, success is said to be often very limited since, sodium reduction tends to have adverse effects both on taste quality as well as flavor perception [8]. As per World Health Organization (WHO) recommendation, an adult individual is permitted to consume $<5 \mathrm{~g}$ of salt per day in order to prevent chronic diseases associated with high sodium intake. Asian countries have been estimated to consume much higher levels of $12 \mathrm{~g} /$ day. In western countries, $75 \%$ of the sodium is believed to be contributed mainly by processed foods and the foods eaten outside other than home food $[9,10]$.

\section{Concerns for Food Industry With Reference to} Sodium Reduction

Sodium chloride is one of the most commonly used food additives, because it is low cost and has the ability to increase one's liking of foods via bringing about modification in flavor and other functional parameters in a food matrix [11,12]. Sodium chloride is indispensable in food processing. It is normally added to achieve technological properties such as dough development in bread and it also helps to bind water in meats. Thus, it helps to preserve the products. It has been reported that the sodium content of many food products exceeds the maximum set limits and such levels are thought to produce positive sensory effects [13]. A survey was carried out in UK among the food manufacturers to collect responses regarding the usage of sodium chloride in a wide variety of processed foods. The commonly cited response was that salt imparts appetizing flavor and the constraint to reduce sodium content in food was that it is known to greatly affect the palatability and consumer preference [14]. As sodium reduction is known to reduce food acceptability, it would increase the pressure on the food manufacturers to maintain and retain current sodium levels in processed foods. Sodium reduction in a food matrix is known to have greater impact on the overall taste perception. The major areas of concern include the following aspects.

\section{Loss of Palatability and Reduced Consumer Acceptance}

In a food choice taste is considered as the major governing factor. Humans and animals are known to have liking towards salty taste [15]. Therefore, when there is a greater reduction in the level of salt, consumer acceptance 
would tend to decline [16, 17]. A gradual small incremental decrease in the amount of added sodium is thought to be effective since consumers may not be able to detect the level of reduction up to certain point [18]. A continued reduction in the amount of sodium added to a food product inevitably leads to a saturation point at which a difference in flavor profile would reach a detectable level and the resultant effect is reduced food acceptability. Investigation by Lukas et al. [19] demonstrated that sodium reduction in a meal component to the extent of $>50 \%$ was found to have only a minor decrease in liking. Thus, a large amount of sodium reduction could be achieved. But, the salty taste of sodium needs to be replaced with a suitable substance in order to have positive consumer acceptance.

\section{Textural and other Quality Characteristics}

Reducing sodium chloride level has been demonstrated to negatively affect the textural parameter along with affecting other parameters including moisture level, fat content, $\mathrm{pH}$, starter culture, various additives and even processing conditions [1]. For instance, sodium chloride helps to bind the food constituents such as proteins, fats and even water. Therefore, the meat batters containing low sodium need to incorporate a sodium replacer. This not only helps to achieve salty taste, but also helps to compensate for other functional roles which might be lost when there is low sodium content in a food matrix [20]. Sodium chloride helps to inhibit the growth of yeasts. It also facilitates the development of gluten structure in bread. Therefore, when there is a reduction in the level of sodium chloride, it would increase the risk of rapid spoilage through the growth of yeast colonies and could also affect gluten development which is known to have negative effect on the texture of bread [21]. In cheese preparation if the sodium content is reduced, it could affect the starter culture activity. In US, the food industries are marketing cheddar cheeses with different levels of sodium chloride [22].

\section{Food Preservation and Microbial Safety}

Sodium helps to reduce the water activity and thus limits the growth of pathogens and spoilage microorganisms in a wide variety of food system [23]. Sodium chloride is widely used in meat industry both as a preservative and for palatability, though consumers are now gradually becoming aware of adverse effects of excessive salt consumption [24]. In processed meat products and cheeses, sodium chloride is known to minimize the growth and production of toxin especially by $\mathrm{C}$. Botulinum [25], and others such as sodium diacetate also show similar effect for Listeria monocytogenes and lactic acid bacteria in ready-to-eat meats [26]. On the other hand, sodium reduction would tend to increase the growth of bacteria and bring down the shelf life. When sodium is reduced certain factors such as cooking, packaging and storage temperature should be given utmost importance. Other preservatives need to be added to extend the shelf life. All low sodium products need to be evaluated for its microbiological safety and shelf stability as these qualities are greatly associated with adverse effects on the stored products in low sodium environment [23].

\section{Use of Salt Substitutes}

Due to the adverse effect of high sodium consumption on health, it has become imperative to use a suitable alternative that can compensate for the salty taste along with maintaining normal sensory attributes. The food processing industries have resorted to use salt substitutes to maintain normal sensory attributes of savoury foods. These salt substitutes mimic the pure taste of saltiness and can be incorporated to foods with an objective of maintaining the savoury taste. Sodium chloride replacers such as potassium chloride, calcium chloride and magnesium sulphate are being used to replace or enhance salty taste in a range of food products [27]. These salts, though they are beneficial in contributing salty taste, may also bring about certain undesirable effects such as bitter after-taste, metallic or astringent tastes. Due to this, their use is currently limited in various food manufacturing sectors $[28,29]$. Food grade acids have also been shown to be effective in enhancing the saltiness of sodium. Little and Brinner [30] conducted an evaluation of the sodium chloride and citric acid content of tomato soup to know the taste preference and saltiness. It was observed that, the intensity of saltiness increased along with an increase in citric acid concentration.

The other viable solution to improve the sensory profile of low sodium products would be to incorporate certain flavouring agents such as herbs and spices and flavour potentiating agents. One of the most important flavor potentiating agents is monosodium glutamate (MSG) which is responsible for contributing umami flavor and has been proven to be a good flavor enhancer especially in low sodium chloride products. MSG is known to contain only $12 \%$ of sodium which is comparatively lower than common table salt and its incorporation would help to achieve normal salty taste perception along with maintaining normal sensory attributes without leading to substantial increase in total sodium content of the product [11].

\section{Research Studies on the Sensory Aspects of MSG Incorporated Salt Reduced Products}

The preferred level of salt in any food product can be lowered through a reduction in sodium intake. This should be exercised gradually. Since a sudden reduction would tend to have initially a decreased palatability. This attempt may take several months of effort to accustom to low salt profile of the products. Available evidence suggests that low sodium foods would be more acceptable when prepared by adding acids and other flavouring ingredients in comparison to foods made without adding acid or any flavouring agents. It is also known to cause acquisition of a preference for the newly formulated foods [31]. MSG is known to alter the flavor profiles through which it brings about enhanced palatability.

\begin{tabular}{|c|l|c|}
\hline $\begin{array}{c}\text { Sl. } \\
\text { No. }\end{array}$ & Research study & \multicolumn{2}{|c|}{ Outcome } \\
\hline 1 & Evaluation of the & The palatability of low sodium \\
\hline
\end{tabular}
palatability of sausages chloride sausages upon the addition with low sodium of MSG and calcium glutamate chloride and calcium demonstrated that they were similar gluconate. $\quad$ to that of conventional sausages due to the incorporation of MSG and calcium glutamate [32].

\begin{tabular}{|l|lr|r}
\hline 2 & $\begin{array}{l}\text { Evaluation } \\
\text { acceptability of low } \\
\text { sodium soup. }\end{array}$ &
\end{tabular}

It was observed that the $85 \mathrm{mM}$ sodium chloride soups with the addition of $50 \mathrm{mM}$ of glutamate was highly preferred over the reference soup which had $150 \mathrm{mM}$ of sodium chloride with no glutamate [33].

\begin{tabular}{|l|l|l|}
\hline 3 & $\begin{array}{l}\text { Palatability profile of } \\
\text { different }\end{array}$ & $\begin{array}{l}\text { It was shown that addition of MSG } \\
\text { helped to reduce sodium intake by }\end{array}$ \\
& $\begin{array}{l}\text { prepared with the } \\
\text { addition of MSG. }\end{array}$ & $\begin{array}{l}30 \% \text { along with maintaining } \\
\text { normal taste and flavor profile [34, } \\
\text { 35]. }\end{array}$
\end{tabular}

\begin{tabular}{|l|ll|l}
4 & Reducing & sodium & The study demonstrated that the
\end{tabular} content in ready to eat sodium content could be reduced lentil soup. by up to $40 \%$ by the addition of MSG. The panelists were found to prefer low salt soups especially at higher levels of MSG [36, 37].

\begin{tabular}{|c|c|}
\hline 5. & $\begin{array}{l}\text { Determination of the } \\
\text { concentration of free } \\
\text { glutamate and 5, } \\
\text { ribonucleotides in } \\
\text { balacan (shrimp paste) } \\
\text { and Malaysian cuisines } \\
\text { and its impact on the } \\
\text { sensory attributes of the } \\
\text { product }\end{array}$ \\
\hline
\end{tabular}

Addition of balacan was found to have dose dependent acceptance of the product. Products such as Asam pedas was shown to have linear increase in the intensity of all attributes with the level of added balacan [38].

\begin{tabular}{l|lr|l}
6 & $\begin{array}{l}\text { Determination of } \\
\text { perceptive maps of } \\
\text { dishes varying in } \\
\text { glutamate content with } \\
\text { professional and naïve } \\
\text { subjects }\end{array}$ & $\begin{array}{l}\text { The study utilized permigiano } \\
\text { cheese as a flavor enhancer. The } \\
\text { flavor was noticed to be clearly } \\
\text { identifiable by the trained panelists. } \\
\text { While, for untrained panelists this } \\
\text { difference was not so obvious. } \\
\text { Also, products with umami } \\
\text { ingredients scored little higher for } \\
\text { its taste and complex flavor [39]. }\end{array}$
\end{tabular}


JNutrition and Food Processing

Table 1: Studies on the acceptability profile of low salt products

\begin{tabular}{|c|c|c|}
\hline $\begin{array}{l}\text { Sl. } \\
\text { No. }\end{array}$ & Research study & Outcome \\
\hline 1 & $\begin{array}{l}\text { Sensory attributes and } \\
\text { shelf stability of MSG } \\
\text { incorporated rice } \\
\text { crackers prepared using } \\
\text { different oils. }\end{array}$ & $\begin{array}{l}\text { Addition of MSG to rice crackers } \\
\text { influenced the sensory profile of } \\
\text { products significantly. The sensory } \\
\text { scores for products with spices were } \\
\text { slightly higher compared to those made } \\
\text { without spices. It can be concluded that } \\
\text { the incorporation of MSG to the product } \\
\text { improved the sensory quality as it is a } \\
\text { multifunctional ingredient which acts } \\
\text { on taste perception, intermediary } \\
\text { metabolism, and excitatory } \\
\text { neurotransmission [40]. }\end{array}$ \\
\hline 2 & $\begin{array}{l}\text { Synergistic effect of } \\
\text { MSG and spices on salt } \\
\text { reduction from fried } \\
\text { products }\end{array}$ & $\begin{array}{l}\text { The study revealed that the products } \\
\text { prepared with low sodium content with } \\
\text { different concentration of MSG along } \\
\text { with the incorporation of mixture of } \\
\text { spices was found to exert enhanced } \\
\text { acceptability of the prepared product } \\
\text { and were highly acceptable even with } \\
\text { low sodium content [41]. }\end{array}$ \\
\hline 3 & $\begin{array}{l}\text { Flavor potentiating } \\
\text { effect of MSG on } \\
\text { acceptability profile } \\
\text { reduced tomato } \\
\text { soups tom }\end{array}$ & $\begin{array}{l}\text { The results revealed that the reduction } \\
\text { of salt level had a greater impact on the } \\
\text { taste profile of control product as they } \\
\text { were judged to have a bland taste as } \\
\text { against MSG incorporated samples. It } \\
\text { was also observed that with increase in } \\
\text { the level of MSG incorporation there } \\
\text { was a gradual increase in the scores } \\
\text { given for various sensory attributes. } \\
\text { The pattern of scoring was similar for } \\
\text { each different set of tomato soup with } \\
\text { different levels of salt and spices. This } \\
\text { could be due to the synergistic effect of } \\
\text { salt, spice and added MSG which have } \\
\text { resulted in greater acceptability [42]. }\end{array}$ \\
\hline 4 & $\begin{array}{l}\text { Exploring the } \\
\text { flavour potentiating } \\
\text { effect of MSG on } \\
\text { acceptability profile of } \\
\text { spiced 'Poories'. }\end{array}$ & $\begin{array}{l}\text { MSG definitely improved the } \\
\text { acceptability of poories at all levels of } \\
\text { incorporation. The improvement was } \\
\text { seen even in spice added products } \\
\text { indicating that MSG had a synergistic } \\
\text { effect with spices. Mixture of spices } \\
\text { significantly improved the flavor of } \\
\text { products in comparison to single spices, } \\
\text { though a positive effect was seen for all } \\
\text { [43]. }\end{array}$ \\
\hline 6 & $\begin{array}{l}\text { Sensory attributes of } \\
\text { fresh herb chutneys } \\
\text { prepared using a flavor } \\
\text { enhancer. }\end{array}$ & $\begin{array}{l}\text { Products without MSG obtained lower } \\
\text { scores. As the level of incorporation of } \\
\text { MSG was increased, a consequent } \\
\text { increase in the scoring was noted for } \\
\text { each attribute. Addition of MSG } \\
\text { resulted in amplification of the flavor } \\
\text { profile of the product [44]. }\end{array}$ \\
\hline 7 & \begin{tabular}{l} 
Acceptability profile of \\
tomato soup \\
\multicolumn{1}{l}{ prepared } \\
using flavor \\
potentiator and \\
spices.
\end{tabular} & $\begin{array}{l}\text { The study indicated that the soups } \\
\text { formulated with different spice } \\
\text { combination with the incorporation of } \\
\text { MSG exhibited maximum acceptability } \\
\text { [45]. }\end{array}$ \\
\hline
\end{tabular}

Table 2: Studies on the acceptability profile of the products prepared in our laboratory

\section{Conclusion}

The above studies imply that MSG is the most suitable salt replacer with a great potential to maintain the pleasantness, saltiness, familiarity and taste intensity of various products. Hence, with low sodium chloride it would be possible to achieve greater level of consumer acceptability without substantially adding up to increased sodium consumption. Thus, the prevailing problem associated with high sodium intake could be minimized.

\section{References}

1. Dotsch, M., Busch, J., Batenburg, M., Liem, G., Tareilus, E. et al. (2009). Strategies to reduce sodium consumption: A food industry perspective. Crit. Rev. Food Sci. Nutr, 49: 841-851.

2. Keast, R.S.J., Breslin, P.A.S. (2003). An overview of binary tastetaste interactions. Food Qual. Pref, 14: 111-124.

3. Beauchamp, G.K., Stein, L.J. (2008) Salt Taste. In The Senses: A Comprehensive Reference; Allan, I.B., Akimichi, K., Gordon, M.S., Gerald, W., Thomas, D.A., Richard, H.M., Peter, D., Donata, O., Stuart, F., Gary, K., Jon, H.K., Esther, G., Eds.; Academic Press: New York, NY, USA,; pp. 401-408.

4. Beauchamp, G.K., Cowart, B.J., Mennella, J.A., Marsh, R.R. (1994). Infant salt taste: Developmental, methodological, and contextual factors. Dev. Psychobiol, 27: 353-365.

5. Brown, I., Tzoulaki, I., Candeias, V., Elliott, P. (2009). Salt intakes around the world: Implications for public health. Int. J. Epidemiol, 38: 791-780.

6. Tsugane, S., Sasazuki, S., Kobayashi, M., Sasaki, S. (2004). Salt and salted food intake and subsequent risk of gastric cancer among middle-aged Japanese men and women. Br. J. Cancer, 90: 128134.

7. Asaria, P., Chisholm, D., Mathers, C., Ezzati, M., Beaglehole, R. (2007). Chronic disease prevention: health effects and financial costs of strategies to reduce salt intake and control tobacco use. Lancet, 370: 2044-2053.

8. Keast, R., Dalton, P., Breslin, P. (2004). Flavor interactions at the sensory level. In Flavor Perception; Taylor, A., Roberts, D., Eds.; Blackwell Publishing: Oxford, UK, 228-255.

9. World Health Organization. (2006). Reducing salt intake in populations: Report of a WHO Forum and Technical Meeting, 57 October, Paris, France; WHO: Geneva, Switzerland.

10. James, W.P., Ralph, A., Sanchez-Castillo, C. (1987). The dominance of salt in manufactured food in the sodium intake of affluent societies. Lancet, 329: 426-429.

11. Kilcast, D., den Ridder, C. (2007). Sensory issues in reducing salt in food products. In Reducing Salt in Foods - Practical Strategies; Kilcast, D., Angus, F., Eds.; Woodhead Publishing: Cambridge, UK, 195-199.

12. Hooper, L., Bartlett, C., Smith, G.D., Ebrahim, S. (2002). Systematic review of long term effects of advice to reduce dietary salt in adults. BMJ, 325: 628 .

13. Hutton, T. (2002). Sodium technological functions of salt in the manufacturing of food and drink products. Br. Food J, 104: 126152.

14. Brady, M. (2002). Sodium survey of the usage and functionality of salt as an ingredient in UK manufactured food products. Br. Food J, 104: 84-125.

15. Chandrashekar, J., Hoon, M., Ryba, N., Zuker, C (2006). The receptors and cells for mammalian taste. Nature, 444: 288-294. 
JNutrition and Food Processing

16. Beauchamp, G.K., Bertino, M., Moran, M. (1982). Sodium regulation: sensory aspects. J. Am. Diet. Assoc, 80: 40-45.

17. Mattes, R.D. (1997). Physiologic responses to sensory stimulation by food: Nutritional implications. J. Am. Diet. Assoc, 97: 406-413.

18. Girgis, S., Neal, B., Prescott, J., Prendergast, J., Dumbrell, S., Turner, C. (2003). A one-quarter reduction in the salt content of bread can be made without detection. Eur. J. Clin. Nutr, 57: 616620 .

19. Lucas, L., Riddell, L., Liem, G., Whitelock, S., Keast, R.S. (2010). The influence of sodium on liking and consumption of salty food. J. Food Sci, 76: S72-S76.

20. Xiong, Y.L. (2007). Meat Binding: Emulsions and Batters; American Meat Science Association: Champaign, IL, USA.

21. Cauvain, S.P. (2007). Reduced salt in bread and other baked products. In Reducing Salt in Foods; Kilcast, D., Angus, F., Eds.; CRC Press: Boca Raton, FL, USA, pp. 283-295.

22. Johnson, M.E., Kapoor, R., McMahon, D.J., McCoy, D.R., Narasimmon, R.G. (2009). Reduction of sodium and fat levels in natural and processed cheeses: Scientific and technological aspects. Compr. Rev. Food Sci. F, 8: 252-268.

23. Doyle, M.E., Glass, K.A. (2010). Sodium reduction and its effect on food safety, food quality, and human health. Compr. Rev. Food Sci. F, 9: 44-56.

24. Petit, G., Jury, V., Lamballerie, M. D., Duranton, F., Pottier, L., Martin, J.L. (2019). Salt intake from processed meat products: Benefits, risks and evolving practices. Compr. Rev. Food Sci. Food Saf, Doi: 10:1111/1541-4337.12478. 1-21.

25. Taormina, P.J. (2010). Implications of salt and sodium reduction on microbial food safety. Crit. Rev. Food Sci. Nutr, 50: 209-227.

26. Seman, D.L., Borger, A.C., Meyer, J.D., Hall, P.A., Milkowski, A.L. (2002). Modeling the growth of Listeria monocytogenes in cured ready-to-eat processed meat products by manipulation of sodium chloride, sodium diacetate, potassium lactate, and product moisture content. J. Food Prot, 65: 651-658.

27. Van Der Klaauw, N.J., Smith, D.V. (1995). Taste quality profiles for fifteen organic and inorganic salts. Physiol. Behav, 58: 295306.

28. Reddy, K.A., Marth, E.H. (1991). Reducing the sodium content of foods: A review. J. Food Prot, 54: 138-150.

29. Lawless, H.T., Rapacki, F., Horne, J., Hayes, A. (2003). The taste of calcium and magnesium salts and anionic modifications. Food Qual. Pref, 14: 319-325.

30. Little, A.C., Brinner, L. (1982). Taste responses to saltiness of experimentally prepared tomato juice samples. J. Am. Diet. Assoc, 84: $1022-1027$.

31. Bellisle, F., Tournier, A., Louis-Sylvestre, J. (1989). Monosodium glutamate and the acquisition of food preferences in a European context. Food Qual. Pref, 1(3):103-108.

32. Woodward, D.R., Lewis, P.A., Ball, P.J., Beard, T.C. (2003). Calcium glutamate enhances acceptability of reduced-salt sausages. Asia Pac. J. Clin. Nutr, 12: S35.

33. Ball, P., Woodward, D., Beard T., Shoobridge A., Ferrier, M. (2002). Calcium diglutamate improves taste characteristics of lower-salt soup. Eur. J. Clin. Nutr, 56: 519-523.
Daget, N., Guion, P. (1989). Influence of glutamic acid or its salts on the sensory characteristics of a chicken broth: reduction of sodium intake. Food Qual Pref, 1: 93-101.

35. Yamaguchi, S. (1987) Fundamental properties of umami in human taste sensation. In: Umami: A Basic Taste (Kawamura, Y. \& Kare M. R., eds.), pp. 41-73. Marcel Dekker, New York, NY.

36. Atung, T., Demirag, K. (1993). Influence of monosodium glutamate on flavor acceptability and on the reduction of sodium chloride in some ready-made soup. Chem Mikrobiol Tech \& lebensm, 15: 161-164.

37. Roininen, K., Lähteenmäki, L., Tuorila, H. (1996). Effect of umami taste on pleasantness of low-salt soups during repeated testing. Physiol. Behav, 60: 953- 958.

38. Imada, T., Hao, S.S., Torii, K., and kimura., E. (2014). Supplementing chicken broth with monosodium glutamate reduces energy intake from high fat and sweet snacks in middle aged healthy women. Appetite, 79, 158-165.

39. Sinesio, F., Peparaio, M., Moneta, E., Comendador, F.J. (2010). Perceptive maps of dishes varying in glutamate content with professional and naive subjects. Food Qual. Pref, 21:1034-1041.

40. Prakash, A., Prakash J., Prabhavathi S.N. (2014). Sensory attributes and shelf stability of monosodium glutamate-incorporated rice crackers prepared using different oils. Ad. Food Sci. 36(2): 48-53.

41. Maheshwari, H.M., Prabhavathi S.N., Devisetti, R., Prakash, J. (2017). Determining efficacy of monosodium glutamate for salt reduction in plain and spiced 'poories' through sensory responses. J. Exptl. Food Chem, 3:129.doi:10.4172/2472-.542.1000129. 1-9.

42. Prabhavathi, S.N., Prakash, J. (2016). Flavor potentiating effect of monosodium glutamate on acceptability profile of salt reduced tomato soups. Proceedings of the 2016 International Conference on Food Properties (ICFP2016) Bangkok, Thailand, May 31-June 2.

43. Maheshwari, H.M., Prabhavathi, S.N., Prakash, J. Exploring the flavour potentiating effect of monosodium glutamate on acceptability profile of spiced 'Poories. Ind. J. Nutr. Dietet, 54(3): 265-277.

44. Prabhavathi, S.N., Prakash, J. (2017). Sensory attributes of fresh herb Chutneys prepared using a flavor enhancer. EC Nutrition, $10.1,2017,26-36$.

45. Prabhavathi, S.N., Prakash, J. (2017). Acceptability profile of tomato soup prepared using flavor potentiator and spices. Intern. J. Food, Nutr. Dietet, 5 (2), 65-71. 